\title{
23. Nepazaudēt grūtāk sasniedzamo diasporas kopienu potenciālu
}

\author{
Arta Krūmiṇa
}

\section{Latvijas l̦audis Brazīlijā}

Latvieši Brazīlijā ieradās, sākot ar 19. gadsimta beigām, tomēr lielo plašumu un ǵeogrāfisko apstākḷu dēḷ latviešu kopienas neatkarīgi no konfesijas kaut vienā pilsētā nebija izveidojušās. Toties mūsdienu tehnoloǵiskās iespējas un informācijas aprites ātrums daudziem nu jau trešās vai pat ceturtās paaudzes tautiešiem izraisījis plašāku interesi par Latviju, tāpēc Brazīlijā gan pastāv latviešu kultūras centrs Ižui pilsētā, kur darbojas Eiropas tautu deju kolektīvs ar skanīgo nosaukumu "Staburags", gan darbojas latviešu nedēḷas nogales skola Novaodesā, kur latviešu pēcteči regulāri apgūst latviešu valodu.

Visos mūsdienu Brazīlijas un Latvijas interakciju dokumentos (piemēram, valsts amatpersonu vizītēs) tiek lēsts, ka Brazīlijā dzīvo apmēram 20 tūkst. latviešu, bet konkrēts skaits nav zināms, jo Brazīlijā tautas skaitīšanas datos netiek norādīta etniskā izcelsme.

Brazīlijā dzimušais Hanss Bērziņš ar sievu Elaini un bērniem uz Latviju pārcēlies 2006. gadā. Hansa tēvs Rūdolfs Bērziņš piecu gadu vecumā uz Brazīliju kopā ar savu ǵimeni izceḷoja no Talsiem. Mamma - Dzidra Cerpe-Bērziņa piedzima latviešu kolonijā "Vārpa" Sanpaulu pavalstī Brazīlijas dienvidos. Tur abi Hansa vecāki satikās un nodibināja ǵimeni. Hansa Bērziņa stāsts ir unikāls, jo tikai dažas ǵimenes no Brazīlijas pēc vairākām paaudzēm ir atgriezušās uz dzīvi Latvijā.

19. gadsimta beigās dominējošie izceḷošanas iemesli bija ekonomiskie apstākḷi, daḷa aizbraucēju pirms Brazīlijas jau bija devušies uz Sibīriju, bet nebija varējuši tur iedzīvoties (Lulle, 2010). 1906. gadā Novaodesā, 1907. gadā Nova Europa, 1910. gadā Paríquera-Açú un 1914. gadā Sanžozē dus Kampusā (São José dos Campos) dibinātas pirmās latviešu kolonijas. Lielākā latviešu kolonija "Vārpa" dibināta 1922. gadā. Tieši 20. gs. 20. gados notika intensīvākā Brazīlijas apgūšana, un mūsdienu apzinātie latviešu pēcteči cēlušies no šajos gados izbraukušajiem. Pēc 1921. gada izbraukuši apmēram 2500 cilvēku. Izbraukšanai tolaik bija reǵistrējušies 6000 cilvēku, taču baptistu baznīcas 
aktīvās pretdarbības dēl aizbrauca mazāk par pusi no tiem, kas bija plānojuši to darìt. Izbraucēju aprēķini veikti pēc baptistu draudžu arhīviem, līdz ar to kopējos skaiț̣os varētu nebūt iekḷauti nekristīti bērni un citu konfesiju piederīgie. 1921. gadā uz Brazīliju, uz Novaodesas draudzi, devās baptistu mācītājs, harismātisks līderis Jānis Iṇkis (1872-1958), kurš jau iepriekš bija viesojies Brazīlijā un tiek uzskatīts par 20. gados izcelıjošo tautiešu vadoni. Lai gan izceḷošana bija centralizēta, veidojot kopīgas kases ceḷa izdevumu segšanai (Lulle, 2010; Tupess, 2007; Krakopa, 2007), tomēr ceḷš līdz "apsolìtajai zemei”" bija garš un nogurdinošs. Apstākḷi vēl neapgūtajos Brazīlijas mežu reǵionos bija ḷoti grūti. 30. gados Latvijas presē parādās izziņas, ceḷojumu un dzìvesstāstu raksti par Brazīiju.

\section{Brazīlijas latviešu vēsturiskās sabiedriskās organizācijas}

Pirmā zināmā Brazīlijas latviešu trimdas organizācija bija "Baltijas valstu draugu biedrība", kas tika dibināta 1935. gada 9. februārī Sanpaulu, lai Baltijas valstis un Brazīlija savstarpēji iepazìtu cita citu un lai veicinātu garīgus, intelektuālus un saimnieciskus sakarus. Pēc Latvijas okupēšanas Brazīlijas latvieši 1941. gada 18. novembrī Sanpaulu dibināja Brazîlijas Latviešu palīdzības komiteju. Līdzīgas palīdzības komitejas nodibināja arī Brazīlijas Latviešu baptistu draudžu apvienība (1945) un Riodežaneiro latviešu draudze (1947). Brazīlijā, īpaši Sanpaulu, no 1951. līdz 1957. gadam darbojās arī Daugavas Vanagu organizācija. 1967. gadā Daugavas Vanagu Brazīlijas nodaḷa mēgeināja atjaunot savu darbību ar divpadsmit biedriem, bet tas neizdevās: meklēdami labākus dzìves apstākḷus, lielākā daḷa sabiedriski aktīvo latviešu bija devušies uz attālām Brazīlijas vietām vai uz ārvalstīm.

Latviešu apvienība Brazìlijā (LAB), kas dibināta 1950. gadā Sanpaulu, ir visvecākā tautiskā organizācija, kas darbojas vēl mūsdienās (Gūtmane, 2011). Kā ziṇots 1935. gada laikrakstā "Rìts" (Lulle, 2010), Sanpaulu darbojusies arī latviešu pamatskola. Lai LAB pastāvētu un tajā varētu iesaistīt plašāku skaitu cilvēku, 1972. gadā tika mainīts nosaukums - turpmāk to sauca Latviešu brazīliešu apvienība, un organizācijas biedri varēja būt gan latvieši, gan latviskas izcelsmes brazīlieši un viṇu ǵimenes locekḷi (neatkarīgi no etniskās izcelsmes) (Gūtmane, 2011). Organizācija "Dienvidamerikas un Karību Latviešu apvienība" (DAKLA) ar ilggadējo vadītāju Dainu Gūtmani ir Latviešu brazīliešu apvienības pēctece.

Termins "apsolītās zemes" lietots saistībā ar latviešu izbraukšanas reliǵiskajiem motīviem, skaitliski lielo reliǵisko organizāciju (baptistu) dalībnieku došanos uz Brazīliju harismātiska līdera vadībā (Tēraudkalns, 2003). 
Dienvidamerikas Latviešu apvienības (DALA) dibināšanas kongress notika 1977. gada 16. un 17. aprīlī Sanpaulu Latviešu luterāṇu baznīcā. Kongresā piedalījās pārstāvji no Argentīnas, Venecuēlas un Brazīlijas. Par organizācijas centru izraudzījās Venecuēlu, jo Brazīlijas likumi nepiel̦āva organizācijas, kuru biedri ir no dažādām valstīm. 2006. gadā politisko pārmaiṇu dēḷ Venecuēlā DALA biroju pārcēla uz Brazīliju. Statūti tika pielāgoti jauniem apstākḷiem, un, ņemot vērā, ka latvieši ir arī citās Dienvidamerikas valstīs, piemēram, Meksikā, organizācijas nosaukumu nomainīja - turpmāk to sauca Dienvidamerikas un Karību Latviešu apvienība. Kopš tā laika organizācijas priekšsēde ir Daina Gūtmane, kura bija viena no pirmajām latviešu izcelsmes Brazīlijas jaunietēm, kas devās uz $2 \times 2$ nometnēm (Gūtmane, 2011).

\section{Mūsdienu Brazīlijas latviešu organizācijas}

Populārākajā 20. gados būvētajā latviešu kolonijā "Vārpa" pašlaik dzīvo latviešu pēcnācēji pensijas vecumā, gandrīz visi jaunieši ir pārcēlušies. No astonssimt ciema iedzīvotājiem lielākā daḷa ir brazīlieši, tomēr "Vārpas" galvenajā ielā Avenida Brasil vēl atrodamas mājas ar uzrakstiem: "Dievs tevi mīlē", "Agrākā aptieka", "Darbnīca". Liela daḷa latviešu jaunībā "Vārpu" pameta, lai dotos studēt vai atrastu labāk atalgotu darbu. Daudzi īpašumi, kuri agrāk piederējuši latviešu ğimenēm, pārdoti brazīliešiem. Paši "Vārpas" latvieši ik uz soḷa apgalvoja: "Latviešu te vairs nav." "Vārpas" skolā, kas tika uzcelta par latviešu ziedojumiem, latviešu izcelsmes bērnu vairs neesot (Tamuža, 2012).

Tiek lēsts, ka Brazīlijā dzīvo apmēram 20 tūkst. latviešu (Latviesi.com, 2014), bet nav zināms konkrēts skaits, jo Brazīlijā dokumentos netiek norādīta tautība. Lielākā un aktīvākā latviešu pēcteču kopiena Brazīlijā darbojas Novaodesā, kur atrodas biedrība "Brazīlijas Latviešu kultūras apvienība" (BLKA), tās paspārnē strādā arī Novaodesas Latviešu nedēḷas nogales skola. BLA paspārnē darbojas arī folkloras kopa “Tarkšk,i”.

Lielākais latviešu kultūras centrs atrodas Ižuī Brazīlijas dienvidos. Ižuī darbojas Eiropas tautas deju kolektīvs "Staburags". Lielākā daḷa dejotāju 2015. gada saulgriežu laikā pirmo reizi viesojās ne vien Latvijā, bet vispār Eiropā. "Staburags" piedalījās Sēlijas novada svētkos Jaunjelgavā un 2018. gadā - Latvijas simtgades dziesmu un deju svētkos.

Brazilijas Latviešu kultūras apvienības medija auditorija galvenokārt ir Brazīlijas latvieši, ap 1500 cilvēku. Atsevišķi paziņojumi un raksti sasniedz līdz 5000 lielu auditoriju. Brazīlijas Latviešu kultūras apvienības nākotnes plāni Brazīlijā palielināt auditoriju un elektroniskajam medijam kḷūt arī par drukāto mediju. "Tiek plānots arī drukāts žurnāls, kura uzvedums būtu ne tikai informēt, bet arī ieinteresēt Brazīlijas latviešus apmeklēt Latviju, apgūt latviešu valodu un iedrošināt aktīvāk piedalīties kultūras dzīvē." (Lulle, Ungure, Bužinska 2015) 


\section{Latvijas l̦audis Krievijā}

Latvijai ar kaimiņos esošo Krieviju vēsturiski bijušas ḷoti ciešas saiknes, tāpēc tajā veidojusies nozīmīga latviešu diaspora. Krievijā dzīvojošos latviešus var iedalīt arī pēc ierašanās laika posma: veclatvieši, padomju varas represētie un viņu pēcnācēji, kā arī Padomju Savienības laikā brīvprātīgi aizbraukušie (Vlasova, 2009). Pilsētās (Maskavā, Krasnojarskā, Omskā) un ciemos (Augšbebros, M. Gorkija ciemā Baškortostānā u. c.), kur latviešu un latgaḷu pēcteči dzìvo lielākā skaitā vai kompakti, pēc Padomju Savienības sabrukuma darbojas latviešu organizācijas, vēl pašlaik uzturot dzīvu latviešu valodu un kultūru. Veclatviešu ciemu latviskās aktivitātes atšķiras no pilsētu biedrību aktivitātēm, jo pirmajiem tās joprojām ir ikdiena un dzīvesveids, savukārt pilsētniekiem jāuztur latviskās tradīcijas daudzkultūru vidē.

\section{Veclatvieši}

Par pirmo Krievijā dokumentāli minēto koloniju var saukt Rižkovu Toboḷskas guberņā. Šì kolonija dibināta 1802. gadā. Tās pirmie iemītnieki bija 18. gadsimta beigās un 19. gadsimta sākumā zemnieku nemieros (Kauguru nemieros) notiesātie vidzemnieki (Poriete, 2002). Sākotnēji latvieši uz Krieviju devās piespiedu kārtā - tāda bija cariskās Krievijas alternatīva piespriestajiem sodiem cietumā vai nāves soda izpildei. Dodoties uz Sibīriju, notiesātajiem bijusi izvēle ņemt līdzi gimeni, ko daudzi arī izmantoja (Driķis, 1995; Salmiņa, 2012). Pusgadsmitu vēlāk uz auglīgās zemes plašumiem aiz Urāliem, uz Sibīriju, brīvprātīgi devās arvien jaunas latviešu ğimenes (Poriete, 2002 pēc "Baznīcas Vēstnesis", 1900).

20. gs. 30. gadu beigās Krievijā jau bija izveidojušās vairāk nek 300 latviešu koloniju (Vlasova, 2014). Pirmā latviešu skola Krievijā tika atvērta 1864. gadā Lejas Bulānā. Sākumā no ciema 60-80 bērniem skolu apmeklēja tikai kādi 10-15, turklāt neregulāri. Situācija mainìjās pēc 1890. gada, kad skolu pārṇēma jauni harismātiski mācībspēki un skolēnu skaits strauji pieauga (ik gadu bija vairāk nekā 100 skolēnu) (Turlaja, 1995).

Par unikālo Lejas Bulānas ciemu plašāka sabiedrība Latvijā uzzināja pēc 70. gados aizsāktajām latviešu kinematogrāfistu un pētnieku ekspedīcijām Sibīijā. Viena no pētniecēm - Vaira Strautniece - 1995. gadā laida klajā grāmatu "Lejas Bulāna - latviešu ciems Sibīijāa".

Bēgḷu gaitas Pirmā pasaules kara laikā latviešus aizveda uz Krievijas lielākajām pilsētām, arī Altaja apgabalu. Lielākā daḷa no viņiem pēc Latvijas valsts dibināšanas atgriezās Latvijā, bet daḷa palika Krievijā karjeras vai ideoloǵijas dẹḷ. Pēc boḷševiku revolūcijas Krievijā palika daudzi latviešu strēlnieki, ieṇemdami atbildīgus amatus valsts un saimnieciskajā darbā (Poriete, 2002). Arī šie latvieši apvienojās pēc nacionālā principa, veidojot apvienības un biedrības, kur dominēja latviešu valoda un kultūra (Vlasova, 2014). 


\section{Padomju Krievija līdz 1937. gadam}

Laikā no 1918. līdz 1937. gadam daudzpusīga latviešu sociālā un kultūras dzīve norisinājās Krievijas lielākajās pilsētās. Maskavā darbojās latviešu kultūras un izglìtības biedrība "Prometejs" ar teātri, latviešu skolām un tehnikumiem, Ačinskas Pedagoǵiskajā tehnikumā darbojās Latgaliešu nodaḷa. Līdz 1936. gadam Krievijā strādāja vairākas latviešu izdevniecības, publicējot grāmatas tikai latviešu valodā. Piemēram, 1924./25. mācību gadā Sibīrijas apgabalā bija 30 latviešu skolu ar 1430 skolēniem; latviešu bērni bija nodrošināti ar izglìtību pat labāk nekā citas tautas. 1933./34. mācību gadā PSRS teritorijā darbojušās jau 119 latviešu skolas, no tām 17 vidusskolas, bet L̦eņingradā un Ačinskā - latviešu pedagoơiskie tehnikumi. Kā nozīmīgākā minama latviešu kultūras un izglītības biedrības "Prometejs" izdevniecības ar tādu pašu nosaukumu - "Prometejs" - darbība (1923-1937) (Poriete, 2002). "Prometejs" bija viena no tām organizācijām, kas pulcēja latviešus arī ideoloǵisku apsvērumu dēḷ. Ar tiem bija jārēķinās, jo citādi Maskavā nebija iespējams pastāvēt (Vlasova, 2014). Lielais terors ${ }^{1}$, kuru padomju vara îstenoja no 1937. lïdz 1938. gadam, ne vien apturēja aktīvo latviešu sabiedrisko dzīvi, bet radīja traǵēdijas gandrīz visās Krievijā dzīvojošajās latviešu ǵimenēs. No 1937. gada visas latviešu skolas un baznīcas tika slēgtas.

\section{Padomju varas represētie}

Apkopotās ziņas par 1941. gada 14. jūnijā deportētajiem liecina, ka no 15424 cilvēkiem 80\% bija latviskas izcelsmes (Bambals, Kalnciema, 2007). Citos avotos uzrādīts, ka no 1941. gada līdz kara beigām izsūtītas 14428 personas (Zālìte, Dimante). Otrā pasaules kara beigas 1945. gada 8. maijā atnesa mieru Eiropai. Latvijā beidzās kara posts, bet lielākajai tautas daḷai tas nozīmēja otro padomju okupāciju un komunistu terora turpināšanos. Karagūstekñus un arī daudzus civiliedzīvotājus, it seviški vīriešus (no 16 gadu vecuma), kopumā ap 90000 cilvēku, ieslodzīja filtrācijas (pārbaudes) nometnēs Latvijā vai citur Padomju Savienībā (LOM, 2015). 1949. gadā no Latvijas tika izsūtītas 42975 personas, par kuru nacionālo piederību dati nav pieejami. Liela dạ̣a izdzīvojušo pēc Staḷina nāves, sākot ar 1956. gadu, vairāku gadu laikā atgriezās Latvijā, - šo cilvēku likteṇi pētīti un aprakstīti pamatīgāk (piemēram, Heidemane, 2001; Kalniete, 2001; D. Gekas dokumentālās filmas; Latvijas Okupācijas

Lielā terora laikā tika arestēti teju visi latviešu biedrību locekḷi, visi politiskie emigranti no Latvijas, kuri PSRS bija ieradušies pēc 1920. gada, visi Latvijas pavalstnieki, izṇemot diplomātisko iestāžu darbiniekus, un citi latvieši. Saglabājušies dati par vairāk nekā 22 tūkst. latviešu, kas 1937.-1938. gadā apcietināti un notiesāti. Zināms, ka no viņiem 16573 ir nošauti un apglabāti masu kapos dažādās PSRS vietās (Ohotina, Roginska, 2009). 
muzeja savāktie materiāli u. c.); diemžēl trūkst pētījumu un aprakstu par tiem tautiešiem, kuri palika Sibīrijā un tur dzīvo joprojām. Tieši viṇi, spītējot visam, ir saglabājuši latviešu tautas kultūru Krievijā (Vlasova, 2014).

\section{Brīvprātīgi izbraukušie pēc Otrā pasaules kara}

Padomju Savienības varas gados daudzi latvieši devās uz Maskavu, L̦eņingradu, Novosibirsku un citām lielpilsētām. Iemesli dažādi: mācības, Latvijā nerealizējamas karjeras izaugsmes iespējas, ğimenes veidošana u. c. Pēc Krievijas latviešu kongresa vadītājas Laumas Vlasovas datiem, šo cilvēku saiknes ar Latviju ir visciešākās, tāpēc, iespējams, Krievijā šì tautiešu daļa par latviskās identitātes uzturēšanu rūpējas mazāk nekā tie, kas iebraukuši agrākos periodos. Iemesli: izkliedētās dzīvesvietas un jauktu tautību ǵimenes (Vlasova, 2009, 2014). Pēc 1989. gada tautas skaitǐšanas datiem, Krievijā tobrīd dzīvoja 30000 latviešu. Pašlaik precīzu skaitu uzrādīt nav iespējams, jo tautas skaitīšanā tautība vairs nav jāuzrāda. Savukārt pēc Krievijas latviešu kongresa datiem, šobrīd Krievijā varētu būt ap 15000 latviešu (Vlasova, 2014).

\section{Pēc neatkarības atjaunošanas 1991. gadā}

Līdz ar Mihaila Gorbačova pārmaiṇu laikiem Padomju Savienībā tika veicināta nacionālo kultūras biedrību izveide. 1989. gadā tika sasaukts Krievijas latviešu kongress Maskavā un L̦eņingradā, dažus gadus vēlāk arī Sibīijā, Tālajos Austrumos un Krievijas ziemeḷos. Tā mērķis bija vienot latviešus Krievijā, uzturēt un attīstìt saiknes ar dzimteni un tautiešu organizācijām visā pasaulē. Vlasova uzsver: "Tas pašiem latviešiem bija liels pārsteigums, cik daudz, izrādās, vinuu ir." (Vlasova, 2014) Izveidojās latviešu kultūras biedrības Maskavā, Pēterburgā, Omskā, Tomskā, Krasnojarskā, Magadanā, Smoḷenskā, Pleskavā. Arī reǵionālās apvienības, piemēram, Baškortostānas Latviešu kultūras centrs, apvienoja visus Baškīiijā dzīvojošos latviešus. Šādam modelim dạ̦ēji atbilst arī apvienība "Komi-Baltija", kurā darbojas latviešu kopas no Siktivkaras, Intas un Uhtas. Tika atjaunotas arī vairākas latviešu evan,géēliski luteriskās draudzes. Tās darbojas Maskavā, Pēterburgā, Baškortostānā, Krasnojarskas apgabala Lejas Bulānas ciemā un Magadanā. Baptistu draudze - Omskas apgabala Bobrovkas ciemā (LRVKF, 2015). Tika veidotas pirmās latviešu nedēḷas nogales skolas. Latvieši pulcējās koros un folkloras kopās. 80. gadu beigās, sākoties Trešajai atmodai, daži entuziasti ar Latvijas Kultūras fonda un Latvijas Izglītības ministrijas atbalstu izveidoja latviskas izglìtības misiju, kuras mērḳis bija katru gadu atrast latviešu valodas skolotājus, kas gribētu doties strādāt uz latviešu ciemiem Krievijā. Laika gaitā mainījās finansētāji un programmas, kas nodrošināja skolotāju ierašanos un uzturēšanos Krasnojarskas novada Lejas Bulānā un Krasnojarskā (Salmiņa, 2012). 


\section{Mūsdienu situācija}

Maskava ir vienīgā pilsēta Krievijā, kurā kopš 1994. gada darbojas latviešu nedēlas nogales skola (līdzīgi kā latviešu Rietumu diasporā) - Latvijas Republikas vēstniecības (Krievijas Federācijā) paspārnē esošā svētdienas skola Maskavā. Divdesmit gadu laikā skolu apmeklējuši vairāk nekā 200 audzēkṇu (LRVKF, 2015). No 2010. gada to finansiāli atbalsta Latviešu valodas aǵentūras administrētais Izglìtības un zinātnes ministrijas finanšu instruments un Krievijā strādā skolotāji no Latvijas.

Latvijas valstij jāpieņem būtiski lēmumi par Krievijas latviešu diasporu. Krievijā joprojām dzīvo liels skaits cilvēku, kas jūtas piederīgi latviskai izcelsmei un kultūrai. Līdzšinējā prakse, sūtot no Latvijas valodas skolotājus, ir attaisnojusies, jo tikusi saglabāta būtiska saite ar Krievijas latviešiem. Nepieciešams paplašināt latviešu valodas skolotāju uzdevumus. Bez valodas mācīšanas izglìtības misijas darbiniekiem jābūt arī latviskās kultūras un identitātes nesējiem, kas darba uzdevumos atspoguḷotos arī kā sadarbības projektu iniciatori un veicēji. L̦oti nepieciešamas plašākas iespējas izglïtojošu pasākumu norisē, tas stiprinātu sarūkošo saikni ar Latviju. Diasporas bērni un jaunieši var piedalīties nometnēs Latvijā, tomēr, vērtējot lielās izmaksas, kādas nepieciešamas viena Krievijas bērna un pavadoņa nonākšanai šādā nometnē, jāparedz lielāks finansējums izglîtības un kultūras pasākumiem arī mītnes zemē.

\section{Literatūra un avoti}

Bambals, A., Kalnciema, A. u. c. (2007) Aizvestie. 1941. gada 14. jūnijs. Rīga: Latvijas Valsts arhīvs.

Driķis, J. (1995) Lejas Bulanka. Grām.: Strautniece, V. (sast.) Lejas Bulāna - latviešu ciems Sibirijā. Rīga: Zvaigzne ABC.

Gūtmane, D. (2008) Daina Gūtmane. Virtuālā enciklopēdija, Latvijas l̦audis [http://www.latvijaslaudis.lv/old-data/users/gutmane_daina/ (30.05.2017.)].

Gūtmane, D. (2011) Latviešu trimdas politiskās aktivitātes Brazìijāa. Latviešu trimdas loma Latvijas neatkarības idejas uzturēšanā. LZA Baltijas stratēǵisko pētijumu centrs [http:// www.barikadopedija.lv/raksti/187498 (30.05.2017.)]; https://www.acadlib.lu.lv/arc/ latviesu_likteni_Krievija/latviesi.htm (30.05.2017.)].

Heidemane, T. (2001) Pamātes klēpì Sibìrijā. Rīga: Likteņstāsti.

IBGE (2015) Brazīlijas ġeogrāfijas un statistikas institūts [http://www.sidra.ibge.gov.br/ bda/tabela/protabl.asp $? \mathrm{c}=3209 \& \mathrm{z}=\mathrm{t} \& \mathrm{o}=1 \& \mathrm{i}=\mathrm{P}(30.05 .2017)$.$] .$

Kalniete, S. (2001) Ar balles kurpēm Sibirijas sniegos. Rīga: Jāņa Rozes apgāds.

Krakopa, G. (2007) Nepublicēts studiju kursa "Migrācijas sociologija" darbs. Latvijas Universitāte.

Latviesi.com (2014) Lielā latviešu diaspora ir būtisks pamats Latvijas un Brazīlijas sadarbības stiprināšanai [https://www.latviesi.com/raksti/104487-liela-latviesu-diaspora-irbutisks-pamats-latvijas-un-brazilijas-sadarbibas-stiprinasanai (30.05.2017.)]. 
Latvijas okupācijas muzejs (LOM). Izglītības daḷa (2015) Otrā padomju okupācija: staliinisma terors 1944-1953 [http://www.omip.lv/lv/latvijas-vestures-parskats/otra-padomjuokupacija-stalinisma-terors-1944-1953/ (30.05.2017.)].

Latvijas Republikas vēstniecība Krievija Federācijā (LRVKF) (2015) Latviešu svētdienas skola Maskavā [http://www.mfa.gov.lv/moscow/tautiesiem/latviesu-svetdienas-skola-maskava (30.05.2017.)].

Lulle, A. (2010) Nepublicēts pētījums "Latviešu izceḷošana uz Brazịliju: 20. gs. sākums".

Lulle, A., Ungure, E., Bužinska, L. (2015) Mediju platformas un diasporas mediji: izpratne un vajadzïbas. Latvijas Universitātes Diasporas un migrācijas pētījumu centrs [http:// www.diaspora.lu.lv/petijumi/ (29.05.2017.)].

Poriete, A. (2002) "Mēs esam savējie". Izstādes Latviešu likteņi Krievijā materiāli. Latvijas Universitātes Akadēmiskā bibliotēka [https://dspace.lu.lv/dspace/handle/7/1869].

Salmiņa, L. (2012) Latvieši Krasnojarskā, interneta emuārs [http://lienestasts.blogspot. com/2012/10/latviesi-krasnojarska.html (08.2015)].

Salmiņa, L. (2014) Mağistra darbs "Latviešu diasporas kopienu Sibirijā un Latvijas savstarpējā sadarbïba: sociālo tïklu formas un aktori pēc LR neatkarības atgūšanas". Vidzemes Augstskola, Sabiedrības zinātṇu fakultāte. Studiju programma "Pārvaldība un komunikācija", Valmiera.

Tamuža, B. (2012) Liecību vākšana latviešu kolonijā "Vārpa" Brazìijā [http://latviesufonds.com/ $2011 ? \mathrm{p}=8964 \&$ lang $=1525 \& \mathrm{css}=1 \& \mathrm{~b}=1 \& \mathrm{lbu}=4184$ (30.05.2017.)].

Tēraudkalns, V. (2003) Latviešu izcel̦ošana uz Brazīliju: cēloṇi un ideologiija. Grām.: Reliǵiski-filozofiski raksti, IX sēj. Rīga: LU FSI.

Tupess, M. (1977) Migrācija S. Paulas pavalstī. Brazīlijas Latviešu draugu fonda (BLDF) arhivs, 7. 1pp.

Turlaja V. (1995) Latviešu skolas Jeņisejas guberņā no XIX gadsimta vidus līdz 1937. gadam. Grām.: Strautniece, V. (sast.) Lejas Bulāna - latviešu ciems Sibïrijā. Rīga: Zvaigzne ABC, 303 lpp.

Vlasova, L. (2009) Trīs dažādie latvieši Krievijā [http://lvportals.lv/print.php?id=200462 (30.05.2017.)].

Vlasova, L. (2014) Latviskā kultūra Krievijā. Latvija ārpus Latvijas. Kultūra, vēsture, emigrācija un nacionālā identitāte. Konferences referātu krājums. Rīga: Latvijas Nacionālais arhīvs, 34.-37. lpp.

Zālīte I., Dimante S. (n.d.) Četrdesmito gadu deportācijas. Struktūranalizze. SAB Totalitārisma seku dokumentěšanas centrs [http://lpra.vip.lv/strukturanalize.html (30.05.2017.)].

Охотин, Н. Г., Рогинский, А. Б. (2009) «Большой террор»: 1937-1938. Краткая хроника [http://www.memo.ru/history/y1937/hronika1936_1939/xronika.html (08.2015.)]. 